\title{
A new ulcerative flexibacteriosis-like disease ('yellow pest') affecting young Atlantic cod Gadus morhua from the German Wadden Sea
}

\author{
Ingrid Hilger, Sören Ullrich, Kerstin Anders* \\ Institut für Meereskunde an der Universität, W-2300 Kiel 1, Germany
}

\begin{abstract}
During a survey on diseases of fishes in the German Wadden Sea, young Atlantic cod Gadus morhua with conspicious lesions were found for the first time in winter $1987 / 88$, especially in the estuaries of the Elbe and Weser rivers. The disease affected juvenile cod only, and it occurred in early winter and spring, soon after they had entered the estuaries of the main rivers tributary to the North Sea. Long, slender bacterial rods could be demonstrated frequently in histological preparations of the yellow nodules that typically were associated with the lesions. A Cytophaga-Flexibacter-like bacterium, thought to be responsible for the disease, was isolated and described. The lesions associated with the condition suggest that the disease is lethal to the fish.
\end{abstract}

\section{INTRODUCTION}

Atlantic cod Gadus morhua is one of the commercially most important fish species in the northeastern Atlantic. Commercial fisheries mainly concentrate on stocks inhabiting the coastal waters of Norway, Iceland, Greenland, and Newfoundland, as well as the North Sea and the Baltic Sea.

Research on diseases and parasites of Atlantic cod has to date focused on wild populations, and a number of conspicuous diseases and parasites of wild cod have been reported (Möller \& Anders 1990). These include skeletal deformities (Smith 1867, Lundbeck 1928, Möller 1979, 1983), skin ulcerations (Larsen \& Jensen 1979, Möller 1981, Jensen 1983, Larsen 1983, Bucke 1989), lateral line necrosis (Naeve 1968, Möller \& Anders 1986), pseudobranchial pseudotumour (Morrison et al. 1979, Egidius et al. 1981, Watermann et al. 1982), and the gill parasite Lernaeocera branchialis (Sundnes 1970 . Templeman et al. 1976, Müller 1983). Most of these studies dealt with adult specimens; only a few surveys included studies on juvenile cod (Möller 1984, 1988).

Accompanying the declines in wild cod stocks due to overfishing has been an increasing interest in the farming of Atlantic cod. This is especially true for Norway,

- Addressee for correspondence where cod farming has recently become a valuable branch of the aquaculture industry. With this recent interest in cod culture, the disease findings resulting from the wild cod surveys are likely to take on an increasing significance.

In this contribution, information on a recently discovered disease condition of young Wadden Sea cod is presented. The ulcerative condition is referred to as 'yellow pest' because of its striking external disease signs. The evidence strongly suggests that a bacterial agent of the Cytophaga-Flexibacter group is responsible for the disease.

Among this group of bacteria, there are 3 species that are pathogenic for fish and therefore of significance for aquaculture: Flexibacter columnaris, Cytophaga psychrophila (newly named Flexibacter psychrophilus), and Flexibacter maritimus (Bernardet \& Grimont 1989). These pathogens are responsible for diseases like 'columnaris disease' and 'peduncle or coldwater disease' in freshwater fish species, as well as for an unnamed ulcerative condition of marine species.

\section{MATERIAL AND METHODS}

Sampling. As part of a general survey on fish diseases in the German Wadden Sea from January 1988 to December 1989, young Atlantic cod were caught using 
chartered commercial shrimp trawlers. Three and 6 stations were surveyed monthly in the estuaries of the Elbe and Eider rivers respectively. Additional 23 stations, distributed over the whole Wadden Sea, were also surveyed at 3 mo intervals (Fig. 1). All samples were examined by only 2 experienced persons to minimize identification mistakes. A total of $10801 \mathrm{cod}$ ranging from 7 to $46 \mathrm{~cm}$ in total body length were examined.

Gross examination. Immediately after capture, all fish were examined macroscopically for the presence of externally visible disease signs and for the parasitic copepod Lernaeocera branchialis. Measurements of the total body length of fish were rounded to the nearest centimetre value below the measured one.

Histopathology. For light microscopy, fish tissue samples from ulcerative lesions were fixed immediately after capturing in chilled Bouin's solution. In the laboratory, samples were dehydrated in a graded ethanol series, sectioned at $5 \mu \mathrm{m}$, and routinely stained with Mayer's hematoxylin and erythrosin. For demonstration of bacteria and fungi, Giemsa and Grocott/ Gomori stains were used.

For transmission electron microscopy, tissue samples were immediately fixed in chilled $2.5 \%$ glutaraldehyde in phosphate buffer $(0.1 \mathrm{M}, \mathrm{pH} 7.4)$ for at least $24 \mathrm{~h}$ at $\mathrm{ca} 4{ }^{\circ} \mathrm{C}$. In the laboratory, samples were washed
3 times in chilled phosphate buffer, postfixed in phosphate-buffered $1 \%$ osmium tetroxide for 2 h at ca $4{ }^{\circ} \mathrm{C}$, dehydrated in a graded ethanol series, treated with propylene oxide, and embedded in araldite. Semi- and ultrathin sections were cut using a Reichert-Jung OM 3 ultramicrotome. Semithin sections $(0.5 \mu m)$ were stained with Richardson's staining solution, whereas ultrathin sections were mounted on nickel grids, stained with uranyl acetate and lead citrate, and examined in a Zeiss EM9 S-2 electron microscope.

Bacteriology. For isolation of bacterial agents, whole yellow nodules from lesions of the mouth cavity were taken for cultivation in cytophaga broth according to Pacha \& Ordal (1967). The broth was prepared with Atlantic scawater that had been diluted with distilled water to a final salinity of $20 \%$. A dilution series of the culture was prepared $\left(0\right.$ to $\left.10^{-6}\right)$ in order to ensure that the bacterium present in highest numbers would be obtained in pure culture. Cultures were incubated at room temperature.

For fluorescence microscopy, smear preparations of either nodules or culture medium were made on slides and stained with acridine orange $(\mathrm{AO})$. For preparations derived from cultured bacteria, bacterial suspension in cytophaga broth were examined after $7 \mathrm{~d}$ incubation. For each preparation, $1 \mathrm{ml}$ suspension was filtered through a nucleopore filter $(0.2 \mathrm{um})$ and stained

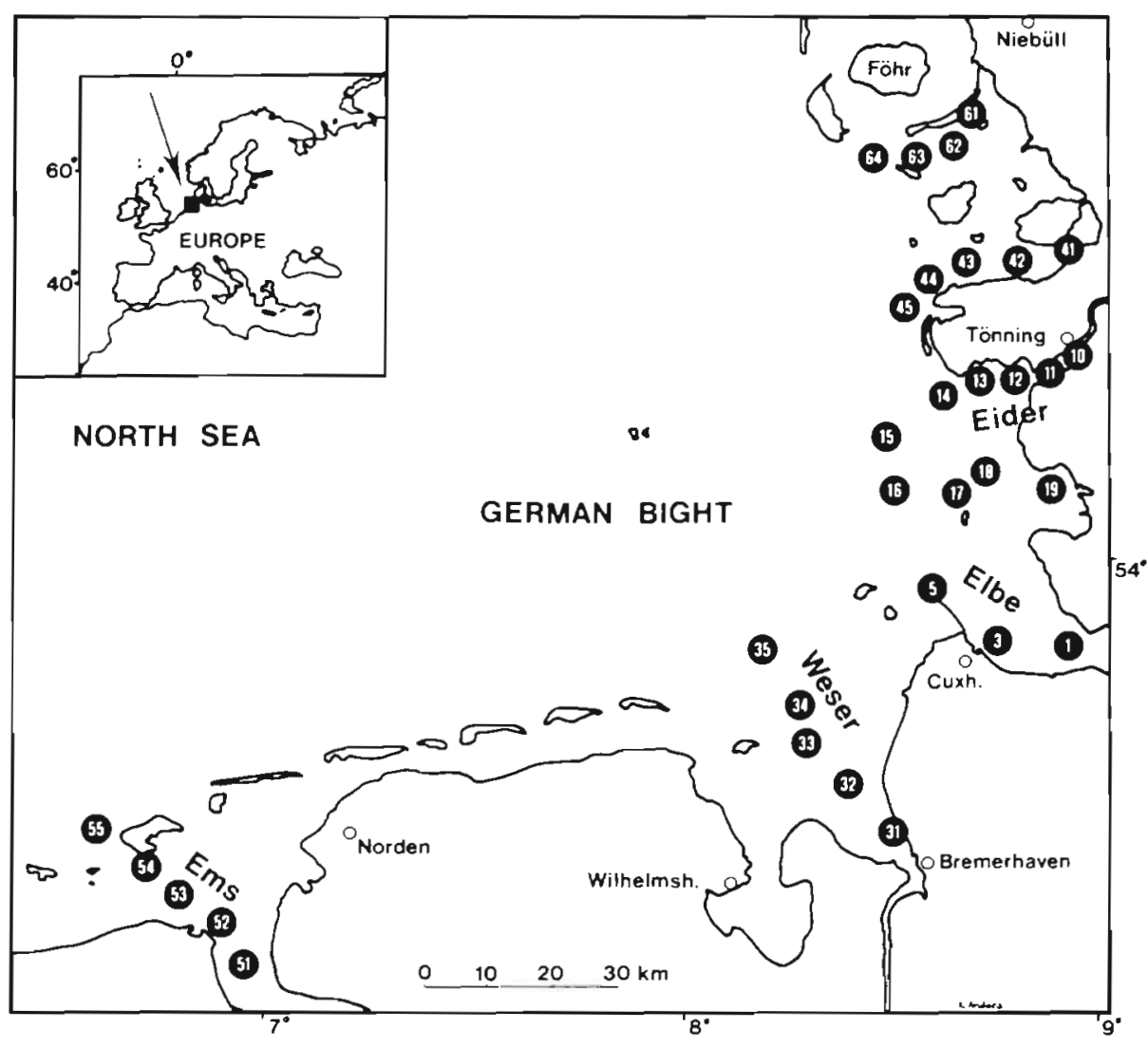

Fig. 1. Research project 'Fish diseases in the German Wadden Sea' Study area and sampling stations, January 1988 to December 1989 
with $\mathrm{AO}$ by another filtration step. Whole prepared filters were used for microscopical examination.

Smears of yellow nodules from 4 fish were taken for fluorescence microscopy and several nodules from 1 fish were cultured.

Characteristics of the isolated bacterium were determined using the following tests: (1) colony pigmentation and shape using cytophaga agar prepared with $20 \%$ Atlantic seawater; (2) motility in inoculated SIM agar test tubes; (3) reaction to Gram stain; activities of (4) cytochrome oxidase, (5) lysine decarboxylase, (6) ornithine decarboxylase, and (7) catalase; production of (8) acetoine (Voges Proskauer test), (9) $\mathrm{H}_{2} \mathrm{~S}$, (10) indole from tryptophan, and (11) mannitol; and (12) the methyl red test. Results of Congo red and $\mathrm{KOH}$ tests were provided by J,-F. Bernardet (Jouy-en-Josas, France). Acid production from carbohydrates was detected in marine oxidation fermentation medium (MOF) according to Leifson (1963). This medium contained $0.1 \%$ peptone (Difco), $0.01 \%$ yeast extract, $0.05 \%$ ammonium sulfate, $0.05 \%$ Tris-buffer, and $0.001 \%$ phenol red indicator. This medium was supplemented with various carbohydrates (glucose, sucrose, arabinose, or cellubiose at $1 \% \mathrm{w} / \mathrm{v}$ ) and sterilized at $115^{\circ} \mathrm{C}$ for $15 \mathrm{~min}$. Gas production from glucose was determined using Durham tubes.

In all biochemical tests, $24 \mathrm{~h}$ old cytophaga broth cultures served as the inoculum.

Bacterial growth in cytophaga broth was studied at different temperatures. Temperatures ranging from 5 to $44^{\circ} \mathrm{C}$ were tested (in increments of $3^{\circ} \mathrm{C}$ ) using a temperature-gradient incubator Turbidity of cultures was determined photometrically at $580 \mathrm{~nm}$ after $90 \mathrm{~h}$ of incubation.

The effect of salinity on growth was tested using cytophaga broth of different salinities $(0,5,10,20,25$, and $30 \%$ ) prepared with Atlantic seawater. After incubation for $50 \mathrm{~h}$ at room temperature, bacterial growth was measured photometrically at $580 \mathrm{~nm}$.

The ability of the bacterium to grow on the following media was also tested: ZoBell seawater broth (ZS), ZoBell brackish water broth (ZB), ZoBell freshwater broth ( $Z F$ ), Marine broth, and tryptose soy broth (TSB) (Table 1).

\section{RESULTS}

During a field survey for externally visible disease signs on fish inhabiting the German Wadden Sea and estuaries of its tributary rivers, only juvenile cod mostly of age group 0 were caught (Hilger 1990). The cod entered the German part of the Wadden Sea in early winter and left it in late spring. During the summer months, cod were almost totally absent from the study areas. Cod affected with 'yellow pest' were found for the first time in winter 1987/88.

\section{Gross morphology of lesions}

Most of the ulcerative lesions were characterized by distinct yellow nodules that ranged from 1 to $2 \mathrm{~mm}$ in size and gave the lesions their striking clear yellow appearance. These nodules varied in shape and were

Table 1. Composition of media used for cultivation of the isolated Cytophaga-Flexibacter-like bacterium (without agar, media were also used as broth). FW: freshwater, DW: distilled water, BW: brackish water (8\% salinity), SW: Atlantic seawater ( $32 \%$ salinity)

\begin{tabular}{|c|c|c|c|c|c|}
\hline Component & $\begin{array}{c}\text { ZoBell } \\
\text { agar }\end{array}$ & $\begin{array}{c}\text { Cytophaga } \\
\text { agar }\end{array}$ & $\begin{array}{l}\text { Tryptose } \\
\text { soy agar }\end{array}$ & $\begin{array}{l}\text { Marine } \\
\text { agar }\end{array}$ & $\begin{array}{l}\text { SIM } \\
\text { agar }\end{array}$ \\
\hline Tryptone & - & $0.5 \mathrm{~g}$ & $15.0 \mathrm{~g}$ & - & - \\
\hline Peptone & $5.0 \mathrm{~g}$ & - & - & $10.0 \mathrm{~g}$ & - \\
\hline Soymeal peptone & - & - & $5.0 \mathrm{~g}$ & - & - \\
\hline Caseine peptone & - & - & $15.0 \mathrm{~g}$ & - & $20.0 \mathrm{~g}$ \\
\hline Beef peptone & - & - & - & - & $6.0 \mathrm{~g}$ \\
\hline Beef extract & - & $0.2 \mathrm{~g}$ & - & $3.0 \mathrm{~g}$ & - \\
\hline Yeast extract & $1.0 \mathrm{~g}$ & $0.5 \mathrm{~g}$ & - & $3.0 \mathrm{~g}$ & - \\
\hline Ammonium citrate & - & - & - & - & $0.2 \mathrm{~g}$ \\
\hline Sodium chloride & - & - & $5.0 \mathrm{~g}$ & $8.0 \mathrm{~g}$ & - \\
\hline Sodium acetate & - & $0.2 \mathrm{~g}$ & - & - & - \\
\hline Sodium thiosulphate & - & - & - & - & $0.2 \mathrm{~g}$ \\
\hline Potassium chloride & - & - & - & $10.0 \mathrm{~g}$ & - \\
\hline Magnesium sulphate & - & - & - & $3.0 \mathrm{~g}$ & - \\
\hline Calcium chloride & - & - & - & $1.5 \mathrm{~g}$ & - \\
\hline Agar & $15.0 \mathrm{~g}$ & $11.0 \mathrm{~g}$ & $15.0 \mathrm{~g}$ & $12.0 \mathrm{~g}$ & $3.0 \mathrm{~g}$ \\
\hline $\mathrm{pH}$ & 7.2 & 7.2 & 7.3 & 7.5 & 7.2 \\
\hline Prepared in $1 \mathrm{l}$ of & FW, BW, SW & $20 \% \mathrm{SW}$ & DW & FW & DW \\
\hline
\end{tabular}



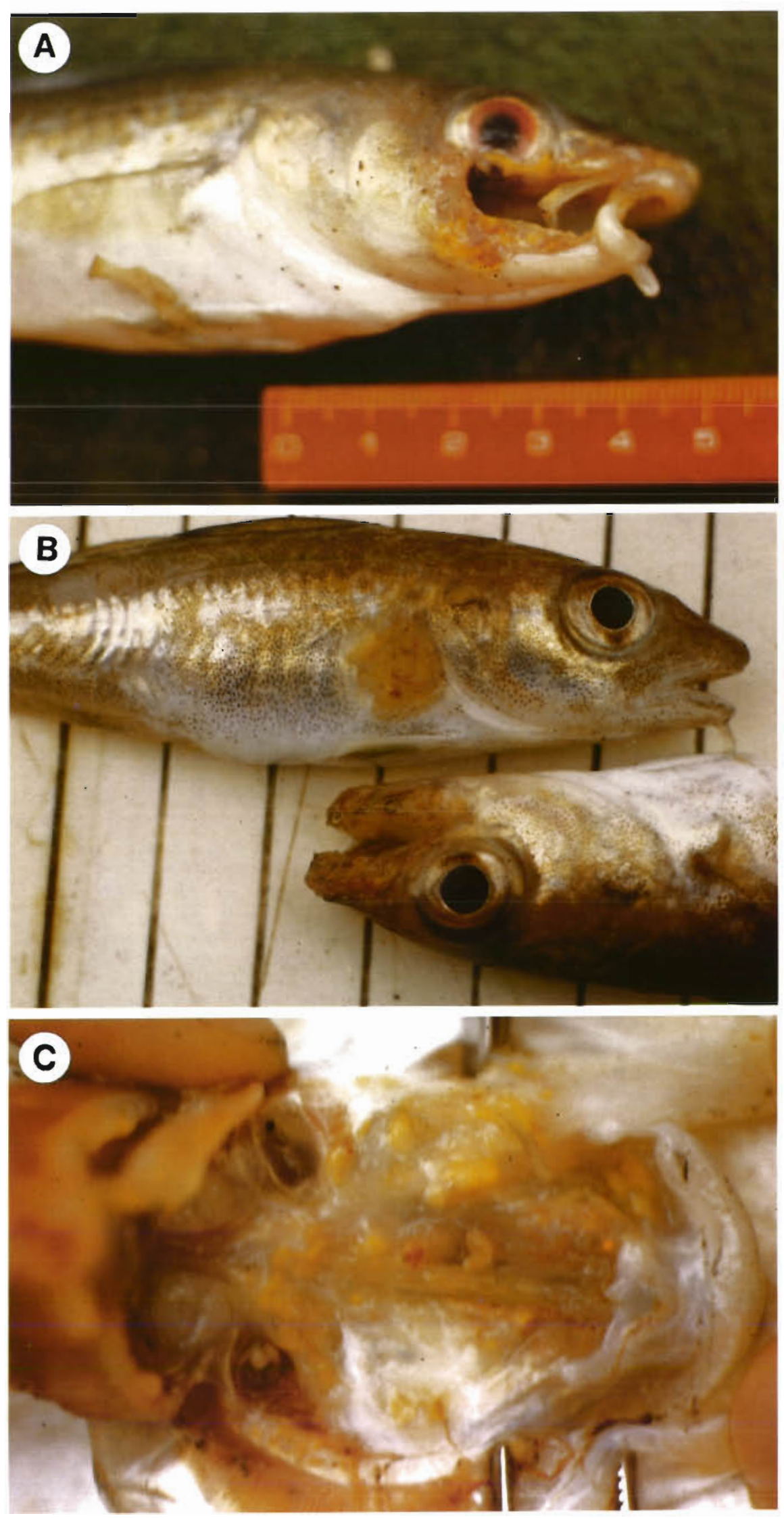

Fig. 2. Cytophaga-Flexibacter-like bacterium infecting Gadus morhua. Typical external signs of 'yellow pest' in young Atlantic cod from the German Wadden Sea. (A) Lateral part of the head, almost totally destroyed (red-yellow appearance); (B) yellowcoloured fin erosion; (C) typical yellow nodules in the palate 
especially numerous in the palate. In other cases red ulcerative wounds were found, some of which contained a few yellow nodules. The lesions were confined to the mouth, fins, and tails of the affected fish. Infected tissue was frequently haemorrhagic. In most cases, severe ulcerative destruction of the integument and of cartilage and bones, especially of the jaws, occurred (Fig. 2).

\section{Epizootiology}

Overall, $0.8 \%$ of the cod were found to be affected with the flexibacteriosis-like ulcerations $(1.1 \%$ in $1988,0.5 \%$ in 1989). Ulcerations were found to be of either a yellowish or a reddish type. The respective prevalences in 1989 were $0.3 \%$ (yellow type) and $0.2 \%$ (red type).

The prevalence of infection was highest in young cod of $13 \mathrm{~cm}$ total body length $(4.3 \%)$ and decreased with increasing length of the fish (Fig. 3).

There was a clear seasonal variation in prevalence of the disease in cod from the Elbe and Eider estuaries. Occurrence of infection was limited to the period November to April. In the Elbe estuary, prevalences in the 11 to $21 \mathrm{~cm}$ length group reached maximum values of 14.7 and $2.6 \%$ in February 1988 and February 1989 respectively (Fig. 4). Cod caught in the Eider estuary displayed a similar tendency. Values decreased thereafter and the disease disappeared in May in both years.

Average prevalences of infection were found to be higher in the estuaries of the Elbe and Weser rivers than in the other areas sampled. For example, in March $1989,2.4 \%$ of the specimens caught in the Elbe estuary and $2.6 \%$ from the Weser estuary were affected. In contrast, lesion prevalence averaged only $0.7 \%$ in the other stations sampled. Values decreased to the west and northeast of these estuaries (Table 2).

In advanced stages of infection, diseased cod showed striking emaciation.

\section{Histopathology}

Affected tissue was characterized by intercellular oedema, hyperplasia or a necrosis of the epidermis. Major pathological changes were evident in the underlying dermis and hypodermis. A reduction of collagen fibres in favour of fibrocytes, blood cells, and blood vessels was observed. Striking necrotic areas were often present in these layers of the integument. These areas were frequently surrounded by collagenous fibres and were equivalent to the macroscopically described 'yellow nodules'.

After Giemsa or Gram staining, strong positive reactions occurred in the necrotic tissue, indicating the occurrence of bacteria (Fig. 5B). In agreement with this finding, semithin sections of necrotic tissue revealed the presence of large numbers of long, slender bacterial rods measuring 10 to $20 \mu \mathrm{m}$ in length. The rods averaged $0.35 \mu \mathrm{m}$ in diameter in ultrathin sections (Fig.

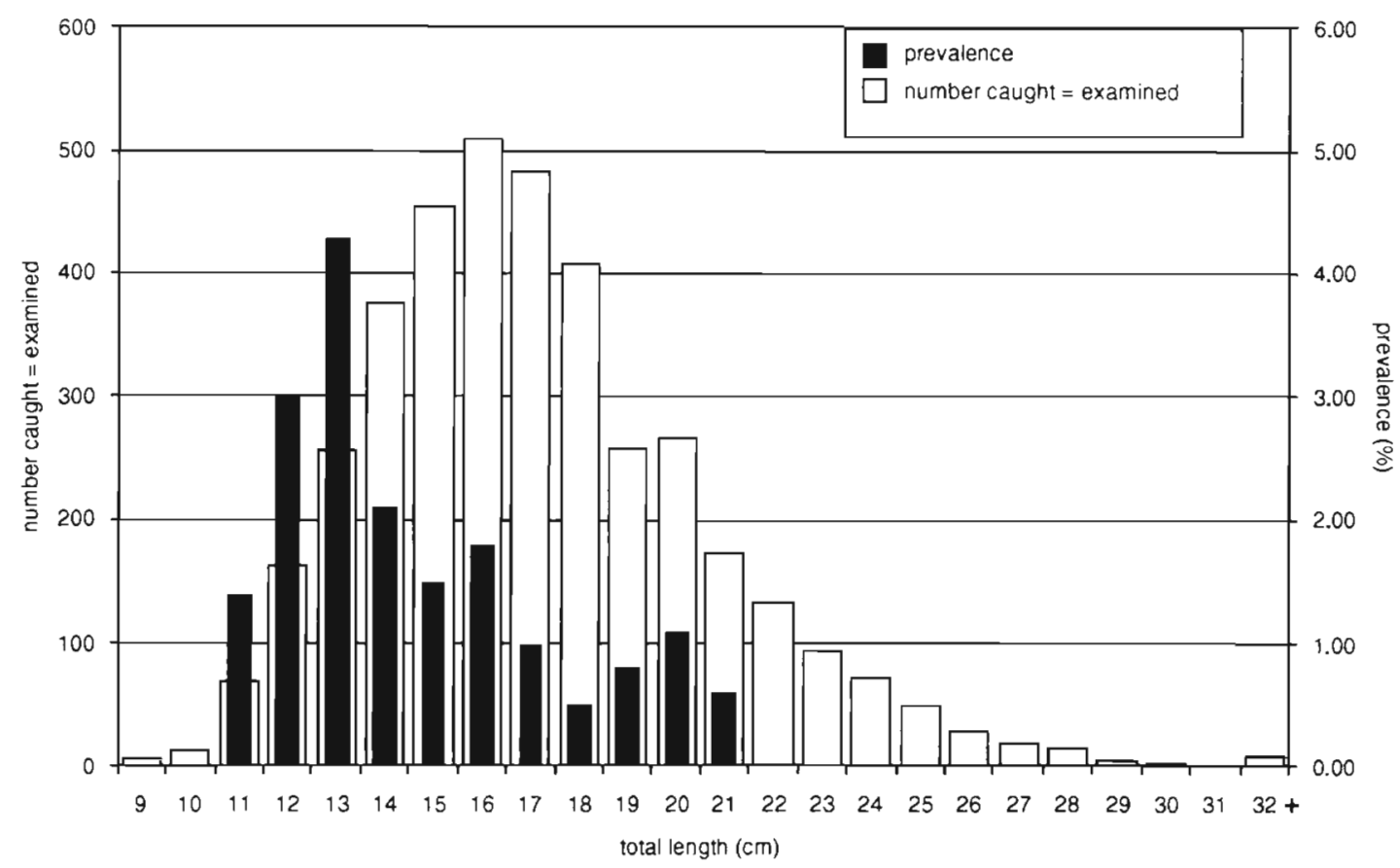

Fig. 3. Cytophaga-Flexibacter-like bacterium infecting Gadus morhua. Relationship between disease prevalence and total length of cod examined. Cod sampled from estuaries of the Elbe and Weser rivers. All data from January to April 1988 and 1989 


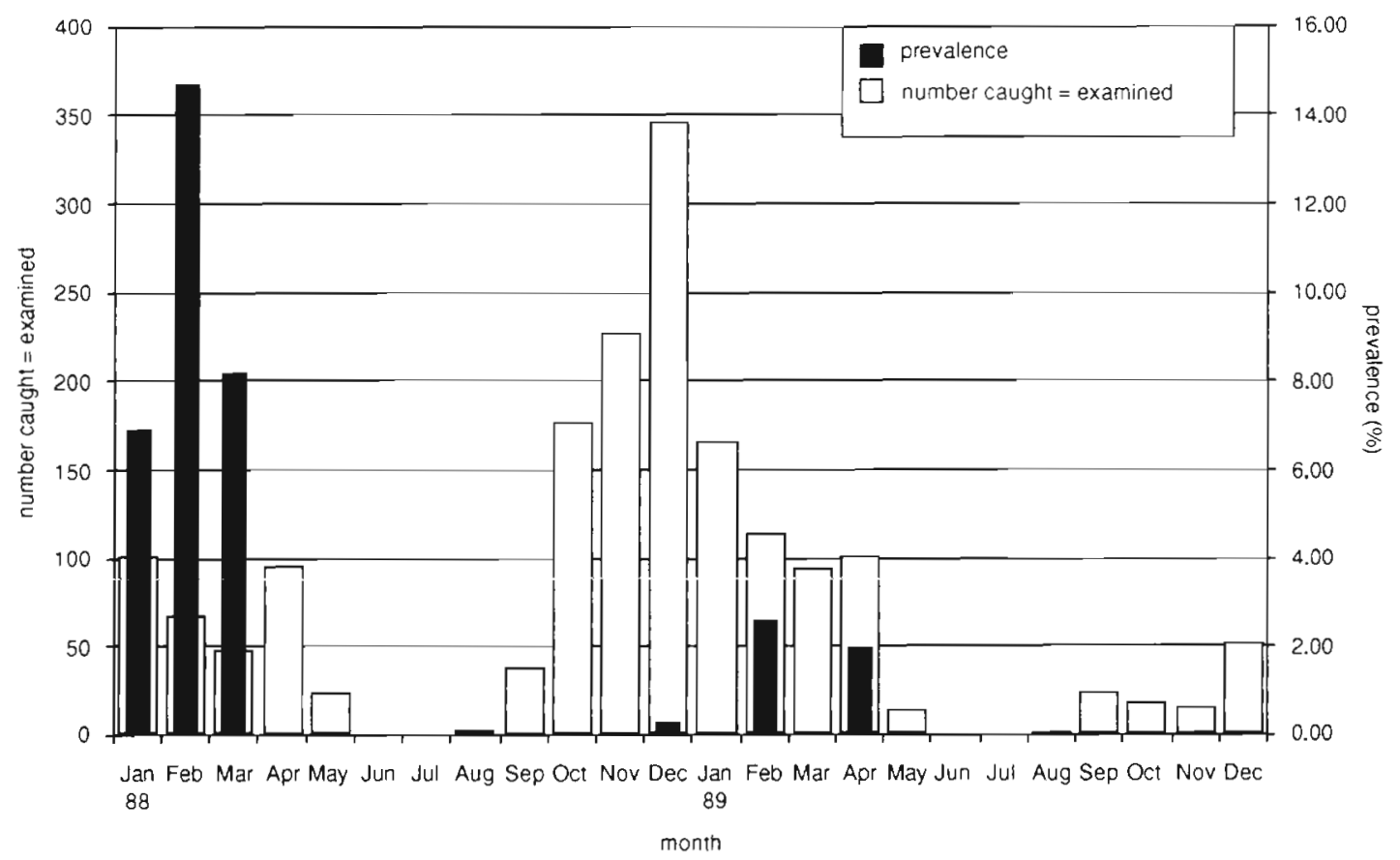

Fig. 4. Cytophaga-Flexibacter-like bacterium infecting Gadus morhua. Seasonal fluctuations in disease prevalence. Cod sampled (11 to $21 \mathrm{~cm}$ total body length) from estuaries of the Elbe and Weser rivers. All data from January 1988 to December 1989

Table 2. Gadus morhua. Regional differences in prevalence of the new flexibacteriosis-like ulcerative disease in Atlantic cod of the German Wadden Sea, January to April 1988, December 1988, and January to April 1989; specimens 11 to $21 \mathrm{~cm}$ total body length. See Fig. 1 for station numbers. N: number examined

\begin{tabular}{|c|c|c|c|c|c|}
\hline Region & Stns & $\begin{array}{c}\text { Salinity range } \\
(\%)\end{array}$ & $\begin{array}{c}\text { Temp. range } \\
\left({ }^{\circ} \mathrm{C}\right)\end{array}$ & $\mathrm{N}$ & $\begin{array}{c}\text { Prevalence } \\
(\%)\end{array}$ \\
\hline Ems River estuary & $51-55$ & $21-30$ & $3-5$ & 101 & 0.9 \\
\hline Weser River estuary & $31-35$ & $11-29$ & $3.5-5.5$ & 337 & 2.6 \\
\hline Elbe River estuary & $1-5$ & $4-25$ & $4-8$ & 1136 & 2.4 \\
\hline Meldorf Bight & $16-19$ & $23-31$ & $3-6$ & 814 & 1.1 \\
\hline Eider River estuary & $11-14$ & $6-31$ & $2.5-6$ & 3038 & 0.9 \\
\hline Hever stream & $41-45$ & $22-32$ & $2-7.5$ & 1239 & 0.2 \\
\hline Süderaue stream & $61-64$ & $23-31$ & $4-8$ & 759 & 0.5 \\
\hline
\end{tabular}

5D). All 16 'yellow nodules' examined from 7 fish contained masses of these rods. Those rods were never seen outside the yellow nodules.

\section{Bacteriology}

Smear samples of infected tissues contained large numbers of long, slender bacterial rods when examined using fluorescent light (Fig. 5C). This morphology is typical of members of the CytophagaFlexibacter group.

Examinations of cultured bacterial suspensions revealed pure cultures of similar long rods at dilutions of $10^{-3}$ and above. Dilutions of 0 to $10^{-2}$ yielded mixed cultures, with Aeromonas hydrophila also being present. The latter was isolated and identified by biochemical tests.

Morphological, cultural, and biochemical characteristics of the isolated Cytophaga-Flexibacter-like bacterium are shown in Table 3 . Gliding motility was observed $2 \mathrm{~d}$ after inoculation. The bacterium grew at temperatures ranging from 6 to $31^{\circ} \mathrm{C}$, and optimally at $23^{\circ} \mathrm{C}$. It also grew at all salinities tested, as well as in freshwater medium; optimal growth occurred at $5 \%$ salinity.

Growth of the bacterium on different broth media is shown in Fig. 6. Growth was observed in nutrient-rich media (TSB, Marine and ZoBell), as well as in the nutrient-poor cytophaga medium. 

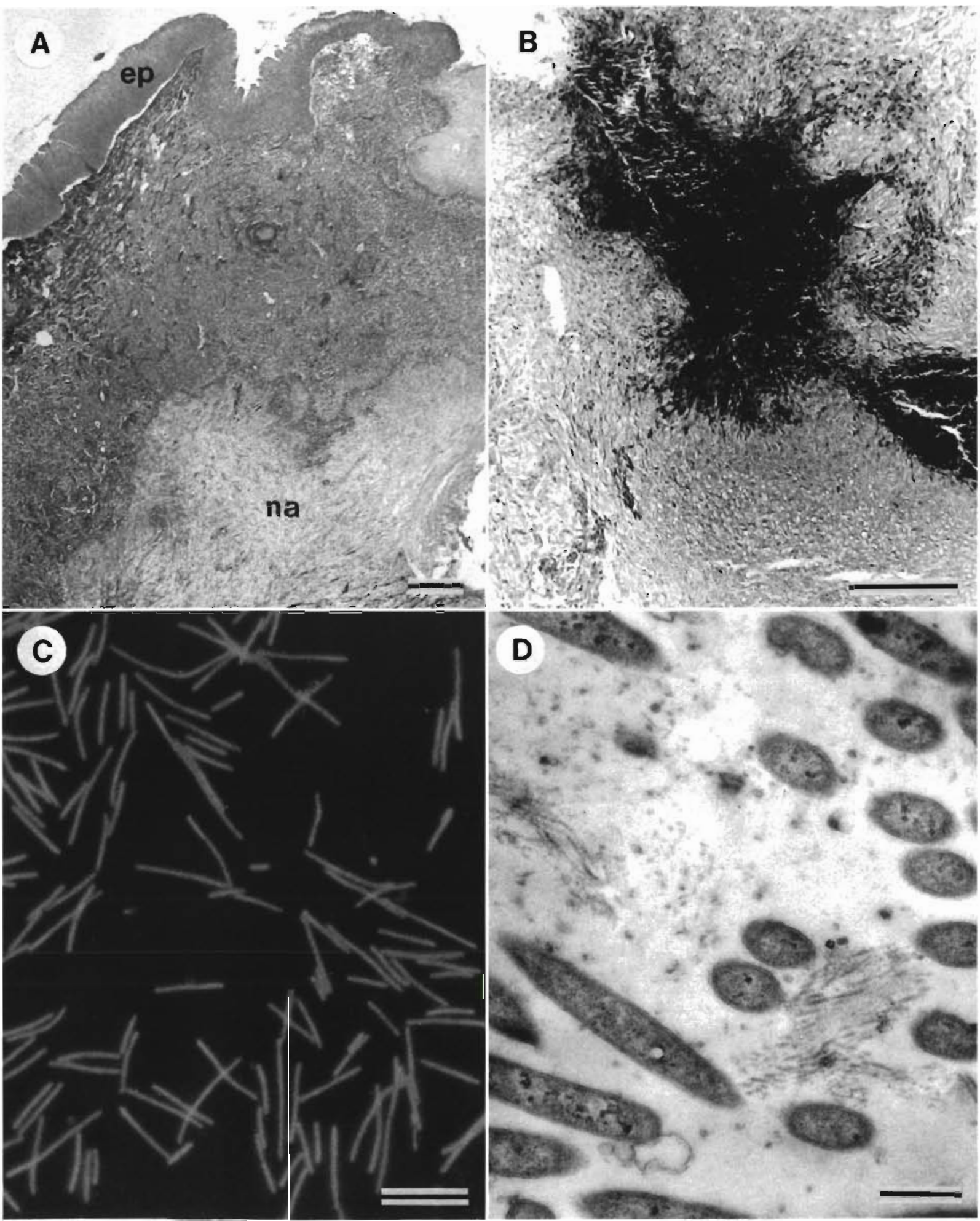

Fig. 5. Cytophaga-Flexibacter-like bacterium infecting Gadus morhua. Results of microscopical examinations. (A) Cross-section through a typical lesion in the palate, with slightly hypertrophic epidermis (ep) and distinct necrotic areas (na), hematoxylin and erythrosin stain. (B) Occurrence of numerous bacteria in necrotic areas ('yellow nodules') of affected tissue, Giemsa stain. (C) Numerous long, slender rods in smear preparation of infected tissue, acridine orange stain. (D) Ultrathin section of bacterial rods. Scale bars are (A) $250 \mu \mathrm{m}$, (B) $100 \mu \mathrm{m}$, (C) $10 \mu \mathrm{m}$, and (D) $500 \mathrm{~nm}$ 
Table 3. Morphological, cultural and biochemical characteristics of the Cytophaga-Flexibacter-like bacterium isolated from Atlantic cod Gadus morhua, compared with other reported Cytophaga and Flexibacter strains. LR: Long rods, Y: yellow, F: flat, C: convex, ND: not determined. Descriptions of known strains are based on published information according to Austin \& Austin (1987)

\begin{tabular}{|c|c|c|c|c|}
\hline Characteristic & $\begin{array}{l}\text { Present } \\
\text { isolate }\end{array}$ & $\begin{array}{l}\text { Flexibacter } \\
\text { maritimus }\end{array}$ & $\begin{array}{l}\text { Flexibacter } \\
\text { columnaris }\end{array}$ & $\begin{array}{c}\text { Cytophaga } \\
\text { psychrophila }\end{array}$ \\
\hline Shape of bacterium & $\operatorname{LR}(5-20 \mu \mathrm{m})$ & $\operatorname{LR}(2-30 \mu \mathrm{m})$ & $\operatorname{LR}(4-8 \mu \mathrm{m})$ & $\operatorname{LR}(2-8 \mu \mathrm{m})$ \\
\hline Colony pigmentation & $\mathrm{Y}$ & Y & Y & $\mathrm{Y}$ \\
\hline Colony shape & $\mathrm{F}$ & $F$ & $\mathrm{~F}$ & $\mathrm{C}$ \\
\hline Gliding motility & + & + & + & + \\
\hline Congo red test & - & + & + & - \\
\hline $\mathrm{KOH}$ test & - & - & + & + \\
\hline Gram stain & - & - & - & - \\
\hline Cytochrome oxidase & + & + & + & + \\
\hline Lysine decarboxylase & + & ND & + & ND \\
\hline Omithine decarboxylase & + & ND & + & ND \\
\hline Catalase & + & + & + & + \\
\hline Voges Proskauer test & + & - & - & - \\
\hline Indole & - & - & - & - \\
\hline Methyl red test & + & - & - & ND \\
\hline $\mathrm{H}_{2} \mathrm{~S}$ production & - & - & + & - \\
\hline Acid production from arabinose & - & - & - & - \\
\hline Glucose & - & - & - & - \\
\hline Sucrose & - & - & - & - \\
\hline Cellobiose & - & - & - & - \\
\hline Mannitol & - & - & - & - \\
\hline Gas production from glucose & - & - & - & - \\
\hline \multicolumn{5}{|l|}{ Growth at: } \\
\hline $5^{\circ} \mathrm{C}$ & - & - & + & + \\
\hline $35^{\circ} \mathrm{C}$ & - & - & + & - \\
\hline $42^{\circ} \mathrm{C}$ & - & - & - & - \\
\hline
\end{tabular}

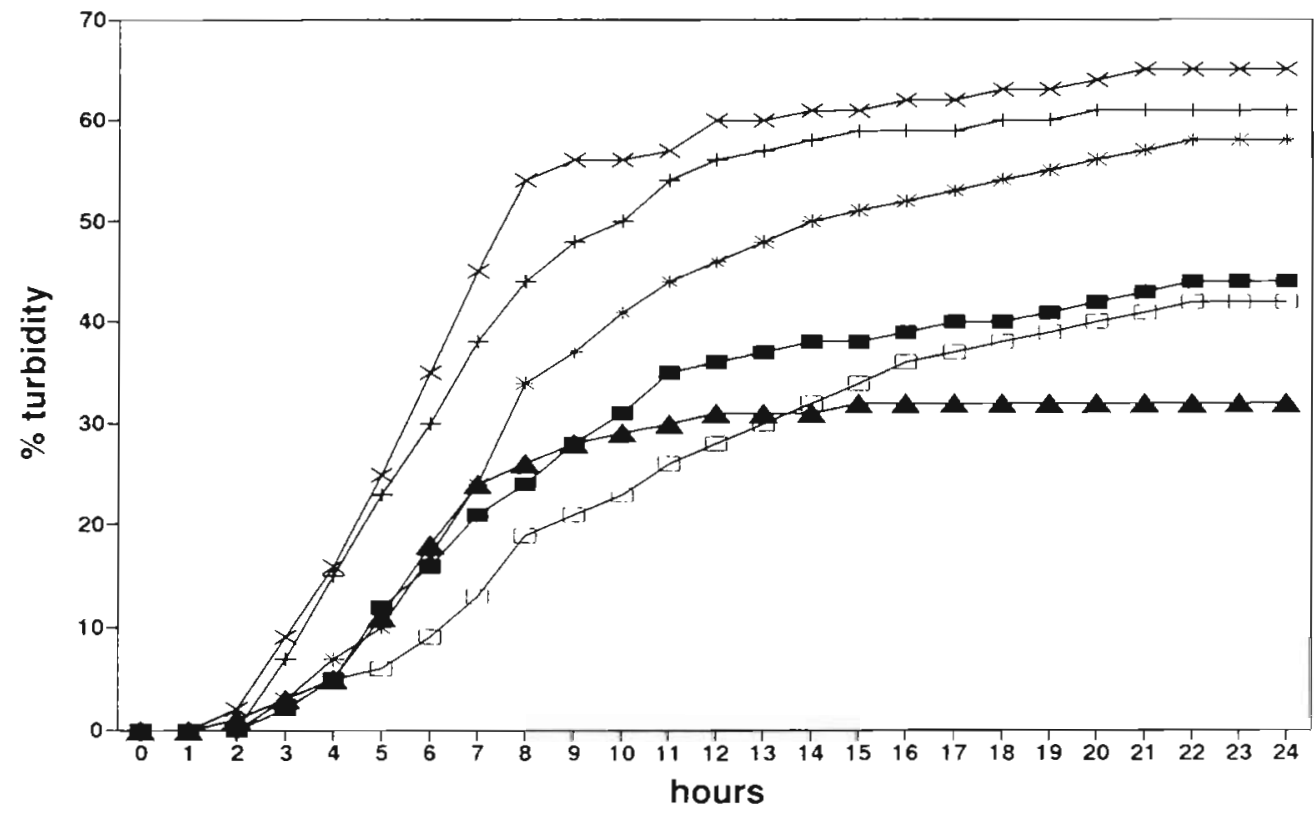

\begin{tabular}{|c|c|c|}
\hline$\rightarrow-Z F$ & + ZB & \# ZS \\
\hline T Cyto & $\nVdash$ TSB & - Marine \\
\hline
\end{tabular}

Fig. 6. In vitro growth patterns of Cytophaga-Flexibacter-like bacterium from Atlantic cod (Gadus morhua) in different broth media (cultivation at room temperature). ZF: ZoBell freshwater broth; ZB: ZoBell brackish water broth (20\%); ZS: ZoBell seawater broth; Cyto: Cytophaga broth; TSB: tryptose soy broth; Marine: marine broth. For broth compositions see Table 1 


\section{DISCUSSION}

The ulcerative condition ('yellow pest') of Atlantic cod described in this study is 1 of 3 very conspicious fish diseases occurring in the German Wadden Sea. However, in contrast to the 2 other diseases, spawning papillomatosis of smelt (Anders \& Möller 1985, Anders 1989) and buccal granulomatosis of smelt (Anders \& Möller 1987), the cod condition appears to be new. Although extensive field studies in the estuaries of the Elbe and Weser rivers have been carried out in the past (Möller 1981, 1984, 1988), this condition had never been seen in cod or in any other fish species. In addition, it has not been reported by other working groups studying fish diseases in the North Sea (Anonymous 1989). However, it should be pointed out that, except for the surveys in the Elbe estuary, most other field studies focused on cod of commercial size, which seem to be unaffected by this disease.

The disease is considered lethal. Data suggestive of this are the generally low prevalence of the disease, its tendency to occur only in young fish (average $13 \mathrm{~cm}$ long), the severe destruction of the affected tissues, the marked emaciation of heavily affected specimens, and the fact that no healing stages or scar formations have ever been observed.

The fact that highest prevalences were found in cod from estuaries of the Elbe and Weser rivers is consistent with the results of investigations on other diseases in these estuaries, especially with respect to flounder Platichthys flesus. In 1981 to 1982 and again in 1984 to 1986, relatively high prevalences of flounder diseases were found in the central estuary of the tidal Elbe River compared to the coastal and freshwater areas of the estuary (Möller 1990). It was hypothesized by Möller that strong tidal and seasonal fluctuations in salinity of the central estuary were responsible for the low biomass of invertebrates (that serve as fish food) found in the estuary. Flounder inhabiting this area become undernourished, perhaps explaining their higher susceptibility to pathogens. The possible role of anthropogenic water pollutants in this location is still unclear despite several attempts to answer this question.

A possible explanation for the seasonal pattern of the disease is as follows. Young cod, free of ulcerations, enter the Wadden Sea area in September/October each year and remain in estuarine situations, where the high population densities in early winter favour the outbreak of the disease. The disease peaks in prevalence in February, and infected individuals die, thus accounting for the disappearance of the condition by April and May (1988 and 1989 respectively). These ideas are based on the assumption that only very young cod are susceptible to the causative agent. Once the cod pass a 'critical (= susceptible) age', they are no longer susceptible to infection.

Considering the results as a whole, it seems likely that the yellow-coloured ulcerations of wild young Atlantic cod were caused by a bacterium of the Cytophaga-Flexibacter group. A second bacterium, Aeromonas hydrophila, also occurred in the lesions but it was always outnumbered by the CytophagaFlexibacter-like bacterium, and the lesions that characterized the condition were typical of those caused by bacteria of the Cytophaga-Flexibacter group.

Only 3 species in the Cytophaga-Flexibacter group have been well described: Flexibacter columnaris and Cytophaga psychrophila, which exclusively affect freshwater fish species, and Flexibacter maritimus, which is restricted to marine fishes. First described by Hikida et al. (1979), F. maritimus has caused distinct yellow-coloured ulcerations and heavy mortalities in cultured marine fish in Japan, especially in juvenile specimens (Kusuda \& Kimura 1982, Wakabayashi et al. 1984, 1986, Baxa et al. 1986). According to Austin \& Austin (1987), this organism has not been reported outside Japan. However, this statement had to be revised when Bernardet \& Grimont (1989) identified F. maritimus as the cause of 'black patch necrosis' (see Campbell \& Buswell 1982) of cultured Dover sole Solea solea in Scotland. Indeed, the syndrome described as 'eroded mouth syndrome' by Anderson \& Conroy (1969) from 1 yr old rainbow trout Oncorhynchus mykiss cultured in sea cages in Scotland may have been due to $F$. maritimus or a related bacterium. Long, slender 'myxobacterial' rods were isolated from the lesions, but a detailed characterization of the organism was, unfortunately, not given. Similar conditions have also been described in North America from salmonids cultured in seawater (Sawyer 1976, Kent et al. 1988).

When results of the biochemical tests and the temperature-and salinity-dependent growth patterns were compared with published characteristics of Flexibacter maritimus, F. columnaris, and C. psychrophila (Table 3, Fig. 6), the isolated strain most closely resembled $F$. maritimus. The isolate differed from $F$. maritimus, however, in the Voges Proskauer, methyl red, and Congo red tests and in its temperature-dependent growth patterns. Furthermore, in contrast to the known strains of $F$. maritimus, which need at least $30 \%$ salinity seawater for growth, our isolate was able to grow in cytophaga broth prepared without seawater. Also, unlike F. columnaris and C. psychrophila, it grew in the agar and broth forms of tryptose soy medium.

As infected cod were found only during the cold winter months with water temperatures ranging from 2 to $8^{\circ} \mathrm{C}$ (Table 2 ), we find it difficult to explain why bacteria did not grow at $5^{\circ} \mathrm{C}$ in vitro.

Primary sites of infection are thought to be the typical 
yellow nodules which eventually developed into yellow-coloured ulcerations. The fact that yellow ulcerations, red ulcerations, and a combination of both were observed suggests that a bacterial succession may occur during the course of the infection. A similar phenomenon has been described in red sea bream Pagrus major that had been infected experimentally with Flexibacter maritimus and Vibrio sp. (Kimura \& Kusuda 1983). The authors suggested that the disease was initiated by F. maritimus, which invaded the body surface of the fish and provided the portal of entry for a subsequent, more serious invasion by Vibrio $\mathrm{sp}$. Another possible explanation is that the lesion is caused solely by the Cytophaga-Flexibacter bacterium and that the resulting ulcerative lesion undergoes a natural evolution.

Further studies are needed to determine whether the disease can be induced experimentally by the isolated strain. In addition, its serological relationship to the known Flexibacter and Cytophaga species and the characteristics of its genome have to be determined.

The potential importance of this disease for the growing cod aquaculture industry, especially in Norway, must not be underestimated. There is already evidence for an involvement of Flexibacter-like bacteria in disease outbreaks in cultured Atlantic cod in Norway (Rodseth et al. 1989).

Acknowledgements. Our special thanks are due to $\mathrm{Dr} \mathrm{H}$ Möller (Kiel), Prof. Dr G. Rheinheimer (Kiel), Dr J.-F. Bernardet (Jouy-en-Josas), Mr D. Bucke (Weymouth), Prof. Dr J. Fryer (Corval.lis), Dr M. Kent (Nanaimo), and Dr M. Yoshimizu (Hakodate) for helpful suggestions and comments. This study was part of an extensive field survey on fish diseases in the German Wadden Sea in 1988/89 which was financed by the Governments of Schleswig-Holstein and Niedersachsen (Germany) and the German Federal Environmental Agency.

\section{LITERATURE CITED}

Anders, K. (1989). A herpesvirus associated with an epizootic epidermal papillomatosis in European smelt (Osmerus eperlanus). In: Ahne, W., Kurstak, E. (eds.) Viruses in lower vertebrates. Springer, Heidelberg, p. 184-197

Anders, K., Möller, H. (1985). Spawning papillomatosis of smelt, Osmerus eperlanus L., from the Elbe estuary. J. Fish Dis. 8: 233-235

Anders, K., Möller, H. (1987). Food-induced granulomatosis in European smelt, Osmerus eperlanus. Can. J. Fish. Aquat. Sci. 44: 1848-1854

Anderson, J. I. W. Conroy, D. A. (1969). The pathogenic myxobacteria with special reference to fish diseases. J. appl. Bact. 32: 30-39

Anonymous (1989). Report of the working group on pathology and diseases of marine organisms. Conm. Meet. int. Coun. Explor. Sea C.M.-ICES/F: 14

Austin, B., Austin, D. A. (1987). Bacterial fish pathogens disease in farmed and wild fish. Ellis Horwood Limited, Chichester
Baxa, D. V., Kawai, K., Kusuda, R. (1986). Characteristics of gliding bacteria isolated from diseased flounder, Paralichthys olvaceus. In: Maclean, J. L., Dizon, L. B., Hosillos, L. V (eds.) The First Asian Fisheries Forum. Asian Fisheries Society, Manila, p. 219-222

Bernardet, J.-F., Grimont, P. A. D. (1989). Deoxyribonucleic acid relatedness and phenotypic characterization of Flexibacter columnaris sp. nov., nom. rev., Flexibacter psychrophilus sp. nov., nom. rev., and Flexibacter maritimus Wakabayashi, Hikida, and Masumura 1986. Int. J. system. Bact. 39: 346-354

Bucke, D. (1989). Observations on visceral granulomatosis and dermal necrosis in populations of North Sea cod (Gadus morhua). Comm. Meet. int. Coun. Explor. Sea, C.M.-ICES/ E: 17

Campbell, A. C., Buswell, J. A. (1982). An investigation into the bacterial aetiology of 'black patch necrosis' in Dover sole. Solea solea L. J. Fish Dis. 5: 495-508

Egidius, E. C., Johannessen, J. V., Lange, E. (1981). Pseudobranchial tumours in Atlantic cod, Gadus morhua L., from the Barents Sea. J. Fish Dis. 4: 527-532

Hikida, M. Wakabayashi, H., Egusa, S., Masumura, K. (1.979). Flexibacter sp., a gliding bacterium pathogenic to some marine fishes in Japan. Bull. Jap. Soc. Sci. Fish. 45: $421-428$

Hilger, I. (1990). Kondition und Gesundheitszustand des Dorsches im Wattenmeer 1988-1989. Diplom thesis, Kiel, 100 pp.

Jensen, N. J. (1983). The ulcus syndrome in cod (Gadus morhual: a review. Rapp. P.-v. Réun. Cons. int. Explor. Mer 182: 58-64

Kent, M. L., Dungan, C. F., Elston, R. A., Holt, R. A. (1988) Cytophaga sp. (Cytophagales) infection in seawater penreared Atlantic salmon. Salmo salar. Dis. aquat. Org. 4: $173-179$

Kimura, H., Kusuda, R. (1983). Microbial succession in gliding bacterium infection in red sea bream. Bull. Jap. Soc. Sci. Fish. 49: 1553-1559

Kusuda, R., Kimura, H. (1982). Characteristics of gliding bacterium isolated from cultured yellowtail Seriola quinqueradiata. Bull. Jap. Soc. Sci. Fish. 48: 1107-1112

Larsen, J. L. (1983). Bacterial aspects of the ulcus syndrome in cod. Rapp. P.-v. Réun. Cons. int. Explor. Mer 182: 65-71

Larsen, J. L., Jensen, N. J. (1979). The ulcus-syndrome in cod (Gadus morhua). II. A bacterial investigation. Nord. Vet.Med. 31, 289-296

Leifson, E. (1963). Determination of carbohydrate metabolism of marine bacteria. J. Bact. 85: 1183-1184

Lundbeck, J. (1928). Beobachtungen über Mißbildungen und Erkrankung von Dorschen an der ostpreußischen Küste. Z. Fisch. 26: $457-472$

Möller, H. (1979). Geographical distribution of fish diseases in the NE Atlantic. A bibliographic review. Meeresforschung $27 \cdot 217-235$

Möller, H. (1981). Untersuchungen über den Gesundheitszustand der Unterweser-Fische. GKSS Forschungszentrum Geesthacht, 56 pp.

Möller, H. (1983). High skeletal deformation rates of cod in the Elbe estuary. Bull. Eur Ass. Fish Pathol. 3: 7-8

Möller, H. (1984). Daten zur Biologie der Elbfische. Möller Publications, Kiel

Möller, H. (1988). Fischbestände und Fischkrankheiten in der Unterelbe 1984-1986. Möller Publications, Kiel

Möller, H. (1990). Association between diseases of flounder (Platichthys flesus) and environmental conditions in the Elbe estuary, FRG. J. Cons. int. Explor. Mer 46: 187-199 
Möller, H., Anders, K. (1986). Diseases and parasites of marine fishes. Möller Publications, Kiel

Möller, H., Anders, K. (1990). Diseases and parasites of marine fishes. 100 transparencies. Möller Publications, Kiel (editions in English, German, Danish, Swedish, Norwegian, and Spanish)

Morrison, C. M., Appy, R. G., Shum, G., Annand, C., Odense, R. (1979). Histology and the incidence of pseudobranch tumors in Atlantic cod (Gadus morhua) in Halifax harbour Comm. Meet. int. Coun. Explor Sea, C.M.-ICES/E: 31

Müller, H. (1983). The effects of Lernaeocera infestation on cod (Gadus morhua). Bull. Eur. Ass. Fish Pathol. 3: 21-22

Naeve, H. (1968). Die Endigung afferenter Fasern der Seitenliniennerven im Mittelhirn des Dorsches Gadus morhua. Mar Biol. 1: 257-262

Pacha, R. E., Ordal, E. J. (1967). Histopathology of experimental columnaris disease in young salmon. J. comp. Pathol. 77: 419-423

Rodseth, O. M., Hjeltnes, B., Knappskog, D. H. (1989). Current status of diseases in intensive culture of cod (Gadus morhua), turbot (Scophthalmus maximus), and halibut (Hippoglossus hippoglossus) in Norway. In: IVth International Conference of the EAF. European Association of Fish Pathologists, Santiago de Compostela (Spain), p. 29

Sawyer, E. S. (1976). An outbreak of myxobacterial disease in

Responsible Subject Editor: Dr T. Evelyn, Nanaimo, B. C., Canada coho salmon (Oncorhynchus kisutch) reared in a Maine estuary. J. Wildl. Dis. 12: 575-578

Smith, J. A. (1867). Notice of various specimens of the deformed variety of Morhua vulgaris, the common codfish - the 'Lord Fish of Yarel - recently taken in the Firth of Forth. Proc. R. phys. Soc. Edinb. 3: 302-303

Sundnes, G. (1970). Lernaeocera branchialis (L.) on cod (Gadus morhua L.) in Norwegian waters. Institute of Marine Research, Bergen

Templeman, W., Hodder, V. M., Fleming, A. M. (1976), Infection of lumpfish (Cyclopterus lumpus) with larvae and of Atlantic cod (Gadus morhua) with adults of the copepod, Lernaeocera branchialis, in and adjacent to the Newfoundland area, and inferences there from inshore-offshore migrations of cod. J. Fish. Res. Bd Can. 33: 711-731

Wakabayashi, H., Hikida, M., Masumura, K. (1984). Flexibacter infection in cultured marine fish in Japan. Helgoländer Meeresunters. 37: 587-593

Wakabayashi, H., Hikida, M., Masumura, K. (1986). Flexibacter maritimus $\mathrm{sp}$. nov., a pathogen of marine fishes. Int. $J$ system. Bact. 36: 396-398

Watermann, B., Dethlefsen, V., Hoppenheit, M. (1982). Epidemiology of pseudobranchial tumours in Atlantic cod (Gadus morhua) from the North Sea and the Baltic Sea. Helgoländer Meeresunters. 35: 425-437

Manuscript first received: July 18, 1990

Revised version accepted: April 22, 1991 